\title{
EFFECT OF MARKETING INTERMEDIARIES ON PRICING OF ONIONS IN BENUE STATE, NIGERIA
}

\author{
Ali Ocholi ${ }^{1 \bowtie}$, Ayilla Vivien Nguwasen ${ }^{1}$, Monica Udeh ${ }^{1}$ \\ ${ }^{1}$ Federal University of Agriculture, Nigeria
}

\begin{abstract}
The study examined the effect of marketing intermediaries on onion prices in Benue state, Nigeria. A multistage sampling method was employed to select 150 onion sellers in the study area. Primary data were collected using a structured questionnaire administered to respondents. Data collected were analysed using descriptive statistics, marketing efficiency and Gini coefficient. The study revealed that the majority (66.7\%) of the respondents were female, $46.7 \%$ were married with an average age of 38 and an average income of $\$ 96684.00$. The result also showed e marketing efficiency of 5.19 indicating that the product was efficient in the study area and Gini coefficient of 0.29 indicating that onion marketing is perfectly competitive. Transportation and storage facilities constituted the greatest challenge faced by onion sellers in the study area. Based on the findings of the study, it was recommended that the sellers should form cooperatives to promote bulk purchase which will, in turn, reduce transportation charges as well as enable them to achieve the benefits from economies of scale.
\end{abstract}

Keywords: vegetables, onions, pricing efficiency, markets, marketing

\section{INTRODUCTION}

Onion (Allium cepa) is a perishable agricultural product that goes bad rapidly if a preservation method is not applied. It is an important vegetable crop belonging to the Amaryllidacea family (Obasi and Kalu, 2019). It is known as "garden" or "bulb" onions and is one of the oldest cultivated vegetables in history. Onion is the most widely used flavouring vegetable crop of major commercial importance throughout the world. It is believed to have originated from tropical central, or western Asia (FAO, 1984, Sulumbe et al., 2015). The leaves are bluish-green and hollow, the bulbs are large, fleshy and firm (Azu et al., 2007). Onion is cultivated throughout Nigeria under a wide range of climatic conditions and it can be biennial, triennial or perennial. The total surface area dedicated to the onion in the world has doubled reaching 2.74 million hectares (Pelter et al., 2000; FAO, 2002; Obasi et al., 2019). Onion growing is widely distributed among countries and regions in the world. In the last decade, production figures have shown an upward trend with a production volume of 33 million tonnes in 2003 and 64 million tonnes in 2007. This represents a 51.6\% increase, with Nigeria producing 618,000 tonnes in the year 2007 (FAO, 2010). It was also observed in 2011, that 4,277,647 tonnes of onions were produced in Nigeria ranking it the fifth largest producer of onion in the world (FAO, 2012). According to Pelter et al. (2000), Obasi et al. (2019) cultivation of this crop in tropical areas has developed steadily for more than 40 years.

The young green plants are eaten raw in salads, while matured bulb is cooked or eaten raw asit contains essential nutrients which may not beavailable from other sources (Abdulai and Ibrahim, 2004; Sulumbe et al., 2015). They are used in sauces and as flavouring agents in many dishes (Brewster, 1977; Sulumbe et al., 2015).

\footnotetext{
$\bowtie$ Ali Ocholi, Department of Agribusiness, Federal University of Agriculture, Nigeria, e-mail: aliocholi@yahoo.com; https:// orcid.org/0000-0003-0961-3674
} 
It is marketed mainly as a freshvegetable and is widely used in most households beingeffective against the common cold, heart diseases, diabetes, osteoporosis,cough and sore throat. It is high in flavonoids which is concentrated on the outer layer of the flesh (Nemeth and Piskula, 2007). It is also rich in vitamin $\mathrm{C}$ and a good source of dietary fibre and folic acid. What is more, in Nigeria, it is ranked second most important vegetable after tomato (Hussaini et al., 2000).

The growing of onions cut across different class and culture. Onions consumption is spread throughout the year and there is a constant demand for onions all year round which, as most of the onion produced in Nigeria come from the Northern Part of the country such as Kano, Sokoto, Bornu, Bauchi, Jigawa, Katsina, Zamfara, createsa problem (Inuwa, 2001; Obasi and Kalu, 2019).

Obasi and Emenam (2014) asserted that marketing usually begins at the farm when the farmers harvest their products. When harvested, the products cannot be transported to the consumer as the consumer is likely to be located far away from the farmers. To adjust supply to meet demand, storage is required. What is more, when harvested, the product is rarely in a form acceptable for consumers, hence it must be sorted, cleaned and processed in various ways and must be presented to consumers in appropriate quality and quantity for sale. (Asogwa and Okwoche, 2012). These activities are carried out by intermediaries in the marketing process.

The production and marketing of onions consist of a multitude of relationships and arrangements which are based on structure - conducting relationship paradigms at each market level - from producers to consumers. In order to ensure a stable supply of onion throughout the year, the market structure should first be considered taking into account the method of production and distribution. The need for market structure analysis in Agricultural marketing has been emphasised by (Clodus and Mueller, 1967; Obasi and Emenam, 2014).

Agricultural marketing is affected by many issues that pose threat to the flow of goods e.g. distance, cost of transportation, seasonal variation, storage, processing, grading and communication (Alabi and Adebayo, 2008). Similar issues are also pointed out by Harrison (1985), Nigatu et al. (2020) who emphasised the marketing problems such as high cost of marketing crops, involvement of many intermediaries to the detriment of farmers and consumers, high physical losses during marketing exposure, insufficient market information to farmers and consumers, lack of grades and standards for the commodities. Afolami (2000), Illo (2016) on the other hand implied the intermediaries had contributed to factors which caused the price of food crops to rise, to the detriment of farmers and consumers.

As a result of the aforementioned problems, over the years one could spot some inefficiencies in the Agricultural marketing including onions. Onions are transported from North to the North central (Benue State) - the long distance has led to increased cost of transportation of onions and storage in inadequate facilities has resulted in damagingof the products (Onions) by heat and also causing it to germinate before it gets to the final consumers leading to losses and influencing the marketing efficiency. The marketing of onion in Benue State has not received adequate attention concerning research especially with regards to the nature of competition and marketing efficiency. Disruption of marketing channels and the price fluctuation constitute a problem in the area. Among the various problems afflicting agricultural marketing in developing economies, research attention will continue to be focused on examining levels of efficiency in different dimensions to suggest strategies for improvement.

Based on that, the research was conducted to examine the effect of marketing intermediaries on onion price in the study area. The specific objectives include:

- describing the socio-economic characteristics of onion sellers in Benue State

- analysing the marketing channels and structure of onion market in the study area

- determining the marketing efficiency of onion sellersin the study area

- identifying the problems affecting onion marketing in the study area.

\section{METHODOLOGY}

\section{Population and sampling method}

The population of the study comprised all onions sellers in fifteen (15) Local Government Areas in Benue State. The Local Government Areas were Ado, Agatu, Apa, Gwer west. Kastina-Ala, Logo, Obi, Oju, Okpokwu, Tarka, Ukum, Makurdi Gboko, Gwer East and Ushongo.

For the study, purposive, multistage and simple random sampling methodwas adopted. In the first stage, a purposive sampling was used to select 10 (ten) Local 
Government Areas based on prior knowledge indicating a high concentration of onions sellers in the area. In the second stage, five wards were selected from each of the ten Local Government Areas making a total of fifty wards. In the third stage, three onion sellers from each of the selected wards were selected using simple random sampling, making a sample size of 150 onion sellers.

\section{Data collection and analysis}

Primary data were collected using a structured questionnaire on the socio-economic characteristics of onion sellers, pricing efficiency, structure and constraint associated with onion marketing in the study area. Prior to the administration of the questionnaires, the questionnaires were pre-tested and necessary corrections were made. Content validity was used to determine the adequacy of the research instrument. In the process, the instrument was thoroughly and independently examined by appropriate experts. The experts gave their critical opinion on the adequacy and relevance of the instrument to the objectives of the study. The observation was harmonised and necessary corrections were made on the instrument before the start of thesurvey. The testretest method was used to determine the reliability of the research instrument. Twenty copies of the research instrument were administered twice to the respondents at given intervals. The two results were correlated and a correlation coefficient of 0.920 was obtained indicating high reliability. The data collected for this study were analysed using both descriptive and inferential statistics. The elements of descriptive statistics such as average, frequency and percentages were adopted to analyse the socio-economic characteristics of onion sellers in Benue State while pricing efficiency, Gini coefficient, average of Likert scale values were used to analyse the effect of marketing intermediaries on onion price in the study area.

\section{Models specification}

\section{Gini coefficient}

Gini coefficient was used to analyse the market structure.

$$
G=1-\Sigma X_{\mathrm{i}} Y_{\mathrm{i}}
$$

where:

$$
\begin{aligned}
& G \text { - Gini coefficient } \\
& 1 \text { - constant }
\end{aligned}
$$

$X_{\mathrm{i}}$ - percentage of onion sellers in the $\mathrm{i}^{\text {th }}$ class of traders

$Y_{\mathrm{i}}$ - cumulative percentage of onion sellers in the $\mathrm{i}^{\text {th }}$ class of traders

$i-1,2,3 \ldots 5$

The Gini coefficient ranges from 0 to 1 , where $0 \mathrm{im}$ plies perfect equality in the distribution (perfect market) and 1 implies perfect inequality (imperfect market), the closer the Gini coefficient is to zero, the greater the degree of equality, and the lower the level of concentration, the more competitive the markets are.

\section{Pricing efficiency}

Pricing efficiency was calculated using the formula given by Khols and Uhls (1967) which was used by Olukosi and Isitor (1990) and later used by Babatunde and Oyatoye (2000) in estimating the marketing efficiency of maize in Kwara State.

The formula specified that:

$$
\text { Pricing Efficiency }=\frac{\begin{array}{c}
\text { value added by } \\
\text { marketing activities }
\end{array}}{\text { marketing costs }} \times 100
$$

$\begin{gathered}\text { In order words, } \\ \text { Pricing efficiency }\end{gathered}=\frac{\text { Net margin }}{\text { Marketing costs }} \times \frac{100}{1}$

where the marketing costs ( $\mathrm{N})$ include: purchase cost, transport cost, loading cost, storage cost, market levy, cost of bags/baskets, local government levy.

\section{Likert scale mean}

A four-point Likert scale was used. The responses were: very important, important, moderate and less moderate.

Their weight were: very important (4), important (3), moderate (2), less moderate (1).

The model for the Likert mean score is given below:

$$
\frac{n_{1} w_{1}+n_{2} w_{2}------n_{4} w_{4}}{\sum n_{1}}
$$

where: $i=n_{1} n_{2} n_{3} n_{4}$

Likert mean score $=[$ (number of people who selected response 1$) \times($ weighing of response 1$)+($ number of people who selected response 2 ) $\times$ (weighing of 
Ocholi, A., Nguwasen, A. V., Udeh, M. (2021). Effect of marketing intermediaries on pricing of onions in Benue State, Nigeria. J. Agribus. Rural Dev., 2(60), 133-141. http://dx.doi.org/10.17306/J.JARD.2021.01379

response 2) ... (number of people who selected response $\mathrm{n}) \times($ weighing of response $\mathrm{n})] /($ total number of respondents).

\section{RESULTS AND DISCUSSION}

\section{Socio-economic characteristics of onions sellers}

Analysis of Table 1 shows that the majority (66.7\%) of the respondents were female. The data implies that the these sellers are more likely to have higher marketing efficiency due to their experience (women are more likely to be sellers and men are more likely to be producers). This results are in line with the work of Sanusi and Dada (2016) who observed that due to gender role in the society, women are mostly involved in the marketing of agricultural products while men are the major producers.

The result also showed that $28 \%$ of respondents are single, $47.6 \%$ are married, $14 \%$ are divorced while $11.3 \%$ are widowed/widower. This implies that most sellers are stable in stable relationshipsand those results are also supported by the study of Abdulazeez et al. (2018) in which, the author states that $62.5 \%$ of the onion sellers were married, $32.4 \%$ were single and only $5 \%$ were divorced.

The result also showed that the majority $(70 \%)$ of the respondents were between the age of 33-42 with mean age of 38. This implies that sellers are in their working age which could lead to an increase in their efficiency. Specifically, $0.7 \%$ are below the age of $22,12.7 \%$ between the age of $23-32,70 \%$ are between the age of $33-42$ while $16 \%$ are older than or are to 43 years old. This study is similar to that of Mamiro et al. (2014) who found that $58 \%$ of onion farmers were middle-aged between 34 and 49 . This age group is considered to be able to perform most of the Agricultural activities.

Table 1 shows that the mean annual income of the sellers in the area was 96,684.00 (\$253.76). The high mean annual income implies that these sellers are more likely to have higher marketing efficiency since such high income influence the adoption of improved marketing practices which translates to higher marketing efficiency. This result is in line with the work of Sanusi and Dada (2016) who reported a positive relationship between household income and marketing margin.

Analysis of Table 1 shows that the household of the majority $(73.3 \%)$ of the respondents consists of 7-10 family members ( 8 people on average). This implies that
Table 1. Socio-economic characteristics of onion marketers $(n=150)$

\begin{tabular}{|c|c|c|c|}
\hline Variable & Frequency & $\begin{array}{c}\text { Percentage } \\
(\%)\end{array}$ & Mean \\
\hline \multicolumn{4}{|l|}{ Sex } \\
\hline male & 50 & 33.3 & \\
\hline female & 100 & 66.7 & \\
\hline \multicolumn{4}{|l|}{ Marital status } \\
\hline single & 42 & 28.0 & \\
\hline married & 70 & 46.7 & \\
\hline divorced & 21 & 14.0 & \\
\hline widow(er) & 17 & 11.3 & \\
\hline Age (years) & & & 38 years \\
\hline$\leq 22$ & 1 & 0.7 & \\
\hline $23-32$ & 19 & 12.7 & \\
\hline $33-42$ & 106 & 70.7 & \\
\hline$\geq 43$ & 24 & 16.0 & \\
\hline Annual income (N) & & & N96684.00 \\
\hline$\leq 20000$ & 3 & 2.0 & \\
\hline $20001-70000$ & 16 & 10.7 & \\
\hline $70001-120000$ & 110 & 73.3 & \\
\hline $120001-170000$ & 17 & 11.3 & \\
\hline$\geq 170001$ & 4 & 2.7 & \\
\hline Household size & & & 8 persons \\
\hline$\leq 6$ & 36 & 24.0 & \\
\hline $7-10$ & 110 & 73.3 & \\
\hline$\geq 11$ & 4 & 2.7 & \\
\hline Experience (years) & & & 9 years \\
\hline$\leq 6$ & 10 & 6.7 & \\
\hline $7-11$ & 121 & 80.7 & \\
\hline $12-16$ & 16 & 10.7 & \\
\hline$\geq 17$ & 3 & 2.0 & \\
\hline Educational level (years) & & & 7 years \\
\hline$\leq 6$ & 104 & 69.3 & \\
\hline $7-12$ & 41 & 27.3 & \\
\hline$\geq 13$ & 5 & 3.3 & \\
\hline
\end{tabular}

Source: field survey, 2019. 
Ocholi, A., Nguwasen, A. V., Udeh, M. (2021). Effect of marketing intermediaries on pricing of onions in Benue State, Nigeria. J. Agribus. Rural Dev., 2(60), 133-141. http://dx.doi.org/10.17306/J.JARD.2021.01379

onion sellers in the study area are more likely to have higher marketing efficiency due to the fact that the higher number of people in the family working together reduces the need for hired labour, thereby reducing costs. This conclusion is consistent with the one of Obasi and Emenam (2014) who stated that the higher number of family members would help increase the marketing efficiency of the sellers because less people would be hired and most of the tasks involved in marketing would be performed by the family members which would lead to the reduction of costs and increase of the marketing efficiency.

The analysis of Table 1 shows that the majority $(80.7 \%)$ of the respondents have been involved in onion selling for 7-11 years ( 9 years on average). This shows that onion sellers in the area have a lot of experience which may also determine the level of knowledge and information in the business and higher level of marketing efficiency. This finding agrees with Aminu (2009) that experience is vital in the adoption of innovations resulting in improved business performance.

The mean of education is 7 years. Specifically, $69.3 \%$ of the sellers had less than or up to 6 years of formal education, $27.3 \%$ had between $7-12$ years of education while $3.3 \%$ have equal to or above 13 years of education. This implies that since onion sellers are fairly educated, they might not be quick to introduceinnovations in marketing. This result contradicts the findings of Onu and Iliyasu (2008) who, in their analysis of food grain marketing in Adamawa State, established that the majority (56\%) of the surveyed sellers attended formal educational institutions which in most cases result in achieving higher marketing efficiency.

The nature of the marketing channel from producer to consumer is shown in Fig. 1.

The marketing channel for onion in the study area is presented in Table 2.

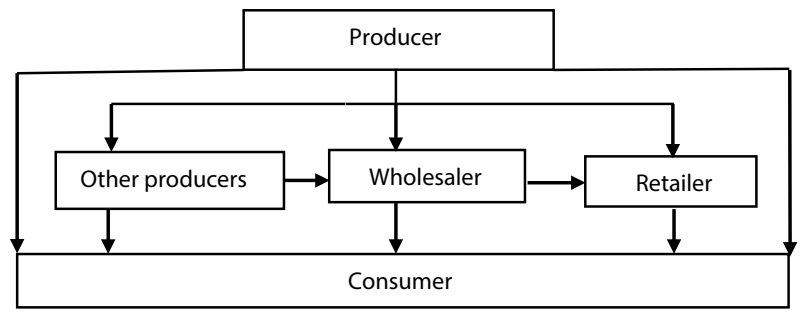

Fig. 1. Marketing channel of onion in Benue State Source: own elaboration.
Table 2. Marketing channel of onion in the study area $(n=150)$

\begin{tabular}{lcc}
\hline \multicolumn{1}{c}{ Variable } & Frequency & Percentage \\
\hline Position in the market & 69 & 46.0 \\
producer & 48 & 32.0 \\
retailer & 33 & 22.0 \\
$\quad$ wholesaler & & \\
Source of purchase & 53 & 35.3 \\
farm gate & 97 & 64.7 \\
rural market & & \\
Major customers & 11 & 7.3 \\
producers only & 48 & 32.0 \\
producer and wholesalers & 46 & 30.7 \\
retailers & 45 & 30.0 \\
consumers & & \\
Distance from area of supply & 30 & 20.0 \\
producer/wholesaler/retailer & 53 & 26.7 \\
wholesaler only & 40 & 14.7 \\
wholesaler/retailer & 22 & 3.3 \\
wholesaler/retailer/consumer & 5.3 \\
consumer only & 53.7 \\
Outlet of sale & & \\
one & & \\
two & & \\
\hline
\end{tabular}

Source: field survey, 2019.

Analysis of Table 2 shows that most (46\%) of the respondents were producers; the majority $(64.7 \%)$ supplied their onion from the rural market; most $(32.0 \%)$ of the customers were producers and wholesalers; most $(35.3 \%)$ onions were sold directly to the consumers, and the majority $(55.3 \%)$ bought goods from two places of sale.

\section{Onion market structure}

Onion market concentration was determined implementing means of the Gini coefficient presented in Table 3. The result of the Gini coefficient for theis market was 0.29 . This implies thatin the study area, the market was perfectly competitive. This reflected the existence 
Ocholi, A., Nguwasen, A. V., Udeh, M. (2021). Effect of marketing intermediaries on pricing of onions in Benue State, Nigeria. J. Agribus. Rural Dev., 2(60), 133-141. http://dx.doi.org/10.17306/J.JARD.2021.01379

Table 3. Gini coefficient for onion sales income by marketers $(n=150)$

\begin{tabular}{lccccccc}
\hline Annual sales (N) & $\begin{array}{c}\text { Number of } \\
\text { marketer }\end{array}$ & $\begin{array}{c}\text { Proportion } \\
\text { of sellers } \\
(X)\end{array}$ & $\begin{array}{c}\text { Cumulative } \\
\text { proportion } \\
\text { of sellers }\end{array}$ & $\begin{array}{c}\text { Annual sales } \\
(N)\end{array}$ & $\begin{array}{c}\text { Proportion of } \\
\text { sales }\end{array}$ & $\begin{array}{c}\text { Cumulative } \\
\text { proportion of } \\
\text { total sales } \\
(Y)\end{array}$ & $X Y$ \\
$\leq 20000$ & 3 & 0.02 & 0.02 & 56400 & 0.004 & 0.004 & 0.00008 \\
$20001-70000$ & 18 & 0.12 & 0.14 & 1048900 & 0.074 & 0.078 & 0.00936 \\
$70001-120000$ & 108 & 0.72 & 0.86 & 10033500 & 0.704 & 0.782 & 0.56304 \\
$120001-170000$ & 17 & 0.11 & 0.97 & 2324300 & 0.163 & 0.945 & 0.10395 \\
$\geq 170001$ & 4 & 0.03 & 1 & 780000 & 0.055 & 1 & 0.03 \\
Total & 150 & & & 14243100 & & & 0.70643 \\
\hline
\end{tabular}

Mean value of sales $=94954 . \mathrm{GC}=1-\Sigma \mathrm{XY}=1-0.70643=0.29$.

Source: field survey, 2019.

of multiple suppliers of the product, with the result that no single supplier could influence supply by increasing or decreasing the quantity supplied to influence price. The conclusions are in line with the ones established by Adeoye and Ibe (2013).

Furthermore, the respondents' opinion on membership to an association, freedom of entry and exit, source of market information, and price fixing were analysed. The distribution of onion marketing by structure is shown in Table 4.

The distribution of respondents by the membership of the market association shows that the majority $(74.7 \%)$ of the respondents were non-member of the market association. This implies that the level of knowledge on supply, demand and prices that market associations provide is more likely to be low in thearea which leads to poor market transparency and hence, lower marketing efficiency. The conclusions are similar to those of Apori-Buabeng (2009) who stated that lack of information leads to a very low degree of market transparency and contributes to marketing inefficiency in the system.

The distribution of respondents by freedom of entry and exit in the study area shows that the majority $(86.7 \%)$ of the respondents agree that there was freedom to buy and sell onion in the market. This indicates that the market is structured to allow freedom of entry and exit of onion sellers and buyers. Since the level of freedom of of entry is connected to the level of concentration (Tung and Wang, 2010), the result indicates that the
Table 4. Distribution of onion marketing by structure in Benue state $(n=150)$

\begin{tabular}{lcc}
\hline \multicolumn{1}{c}{ Variable } & Frequency & Percentage \\
\hline Market association & 38 & 25.3 \\
member & 112 & 74.7 \\
non-member & & \\
Entry and exit & 130 & 86.7 \\
exist & 20 & 13.3 \\
does not exist & & \\
Information source & 116 & 77.3 \\
middle men & 34 & 22.7 \\
market association & & \\
Price determination & 41 & 27.3 \\
purchase price & 109 & 72.7 \\
consumer bargain & & \\
\hline
\end{tabular}

Source: field survey, 2019.

market in the study area is not concentrated and there is no joint profit maximisation among sellers.

Analysis of the distribution of respondents by the source of market information indicates that the majority $(77.3 \%)$ of the respondents obtained their market information from intermediaries. This implies that the intermediaries have a high influence regarding pricing 
Ocholi, A., Nguwasen, A. V., Udeh, M. (2021). Effect of marketing intermediaries on pricing of onions in Benue State, Nigeria. J. Agribus. Rural Dev., 2(60), 133-141. http://dx.doi.org/10.17306/J.JARD.2021.01379

and other marketing decisions in the onion market. This is also supported by Abah et al. (2015).

Furthermore, the majority $(72.7 \%)$ of the respondents in the study area indicated that price fixing for onion was based on the bargaining power of the buyer. This shows that there is a high influence of buyers over sellers with regard to pricing and is indicative of an oligopsony market structure (Abah et al., 2015).

\section{Efficiency of onion marketing}

Analysis of Table 5 shows that the marketing efficiency of onion sellers in the area was 5.19. This implies that for every $\$ 1$ invested in onion marketing, $\$ 5.19$ was obtained by the sellers. Since the value is greater than one, it implies that the onion market in the area was efficient. This agrees with the findings of Obasi and Emenam (2014) who found that the onion market in Abia State, Nigeria is efficient.

Table 5. Estimation of marketing margin and efficiency of onion sellers

\begin{tabular}{lc}
\hline \multicolumn{1}{c}{ Item } & Amount $(\mathrm{N} / 50 \mathrm{~kg})$ \\
\hline Buying price & 449.48 \\
Selling price & 731.98 \\
Marketing cost & 45.57 \\
Marketing margin: B-A & 282.50 \\
Net margin: D-C & 236.93 \\
Marketing efficiency: E/C & 5.19 \\
\hline
\end{tabular}

Source: field survey, 2019.

\section{Constraints to the marketing of onion}

The various constraints limiting the marketing of onion were identified by the respondents. These constraints were ranked using Likert scale and presented in Table 6.

It was established that the major constraint to the marketing of onion as ranked by the respondents was transportation (3.79). This can be attributed to the fact that most of the onions are produced in the northern part of Nigeria, therefore, it is very difficult to transport the product to Benue State as there is significant transportation cost involved due to poor road network.. This finding agrees with Obasi and Emenam (2014) who stated that the major problem encountered by the onion sellers in Abia state in Nigeria was transportation cost. This is
Table 6. Constraints to the marketing of onion in Benue State

\begin{tabular}{lcl}
\hline \multicolumn{1}{c}{ Constraints } & Mean & S.D. \\
\hline Transportation & 3.79 & 0.41 \\
Storage facilities & 3.73 & 0.44 \\
Credit facilities & 3.70 & 0.50 \\
Capital & 3.65 & 0.60 \\
Lack of insurance & 3.53 & 0.62 \\
Tax levies & 3.15 & 0.81 \\
Robbery & 2.81 & 1.07 \\
Seasonality & 2.65 & 1.28 \\
Debt & 2.56 & 1.14 \\
\hline
\end{tabular}

Serious constraints (mean $>2.5$ ).

Source: field survey data, 2019.

also confirmed by the work of Izekor and Abiola (2011) which shows that poor transportation and road network are major constraints to post-harvest losses in green vegetable marketing.

\section{CONCLUSION}

Onion marketers in the area were mostly female, married with large household size, within the active age, well experienced, fairly educated, and high income earners. The structure of the market in the area involved equitable distribution of sales income with free entry and exit. Majority of the sellers were notmembers of market associations who sourced their information from intermediaries. Price depends on consumer bargaining strength; onion sellers in the area were efficient, competitive, and profitable with the purchase of onion accounting for the highest marketing cost. The greatest challenge faced by onion sellers in the area were issues concerning the transportation of goods.

Generally, the data obtained from this research might help the sellers and provide information for potential investors in marketing of perishable agricultural products. It may also facilitate improving the formulation and implementation of food self-sufficiency policies, which will help minimise the perishability of agricultural products and the problems associated with their marketing and distribution, such as spoilage and wastage. 


\section{RECOMMENDATIONS}

Based on the findings, the following recommendations were made:

- Efforts should be made to eliminate the constraints to onion marketing in the study area by improving socio-economic infrastructure such as roads, markets and related facilities.. The Benue State government can fulfil this recommendation by renovating existing bad roads and constructing new ones, especially those that link the points of supply to points of consumption.

- The seller should be encouraged to form cooperativesto promote the bulk purchase and transportation of onion in the area. This will reduce the high cost of transportation involved in the marketing of these commodities as well as enable sellers to achieve the benefits from economy of scale.

\section{REFERENCES}

Abah, D.A., Abu, G.A., Ater, P.I. (2015). Analysis of the structure and conduct of paddy rice marketing in benue state, Nigeria. Am. J. Market. Res., 1(2), 70-78.

Abdulai, A.B., Ibrahim (2004). Economics of Irrigated Onion Production in Endama Area of Gombe State, Nigeria. Maidug. J. Arts Soc. Sci. (MAJASS), 21(12), 17-22.

Abdulazeez, I., Maurice, D.C., Muhammad, A.A. (2018). Analysis of Onion Marketing Structure in Yola North Local Government Area of Adamawa State, Nigeria. Int. J. Sci. Res. Manag. (IJSRM), 6(10), 734-743.

Adeoye, I.B., Ibe, R.B. (2013). Market Structure and Performance of fresh tomatoes in Ibadan Metropolis, Oyo State, Nigeria. In: K. Hannweg, M. Renter (Eds.), Proc. $2^{\text {nd }} A U$ Africa Horticulture Congress (pp. 495-502).

Afolami, C.A. (2000). Inter Temporal and Spatial Pricing Efficiency for maize in Nigeria. Moor J. Agric. Res., 1, 76-85.

Alabi, O.O., Adebayo, C.O. (2008). Net income Analysis of onion producers in Zara Local Government Area of Kaduna state Nigeria. Proceeding of $10^{\text {th }}$ Annual National Conference of Nigeria Association of Agricultural Economics (NAAE) (pp. 41-48). Abuja Nigeria: University of Abuja.

Aminu, A. (2009). Framework for Agricultural Marketing Analysis: theories and application, Ahmadu Bello University Press, Zaria, Kaduna state.

Apori-Buabeng, F. (2009). Market organization and consumers' perception of locally produced rice in the Ashanti region of Ghana. Department of agricultural economics, agribusiness and extension, Kwame Nkrumah University of Science and Technology, Kumasi, Ghana.
Asogwa, B.C., Okwoche, B.C. (2012). Marketing of Agricultural Produce among Rural Farm Households in Nigeria: The Case of Soybean Marketing in Benue State. Int. J. Bus. Soc. Sci., 3(13).

Azu, N.C., Onyeagba, R.A., Nwori, O., Kalu, J. (2007). Antibacterial activity of Allium cepa (onion) and Zingiberofficinale (ginger) on staphylococcus aureus and pseudomonas aeruginosa isolated from high vaginal swab. J. Trop. Med., 3(2).

Babatunde, R., Oyatoye, E. (2000). Food Security and Marketing Problems in Nigeria; the case of Maize Marketing in Kwara State. Retrieved from: https:/www.tropentag. de/2005/abstractslinks/babatundedev4uzi.pdf/assessdpm09/3/11

Brewster, J.L. (1977). Physiology of onions (part 1). Hort. Abs., 47(1), 7-12.

Clodius, R.L., Muller, W.F. (1967). Market structure analysis as an orientation for research in agricultural economics. J. Farm Econ. 49, 515-553.

FAO (1984). Production Year Book (vol. 37).

FAO (2002). FAO statistical data base (online) consultation. 26 March 2003.

FAO (2010). www.faostatvegetableonion/data retrieved 29/10/2011.

FAO (2012). Technical Paper 215/UNP FAO.

Harrison, K. (1985). Improving food marketers in delivery system. In: D. Elz (Ed.), Agricultural Marketing Strategy and Pricing Policy (pp. 28-36). Washington: World Bank.

Hussaini, M.A., Amans, E.B., Ramalan, A.A. (2000). Yield, bulb size distribution and storability of onion (Allium сера) under different levels of N. Fertilization and irrigation regime. Trop. Agric. (Trin.), 77(3), 145-149.

Inuwa, B.B.D. (2001). A study of issues arising from the production of garlic (Allium Sativum) in Nigeria. A paper presented at the training workshop on improving and accelerated garlic production for local and export needs in Nigeria at food crops production technology transfer station (FDA), Dan Hassan, Kano.

Izekor, O.B., Abiola, M.O. (2011). Analysis of postharvest losses in green vegetable (amaranthuscruentus) during marketing in Benin metropolis, Edo State, Nigeria. Int. J. Agric. Econ. Ext. Serv., 1(1), 129-135.

Khols, R.L., Uhls, J.N. (1967). Marketing of agricultural products. New York: Macmillan Publishing Company.

Mamiro, D.P., Maerere, A.P., Sibugal, K.P., Ebaugh, M.J., Miller, S.A., Mtui, H.D., Mgembe, E., Msuya-Bengesi, C.P., Aloyce, A. (2014). Local Community Knowledge on onions Production, Pests and Pests Management in Kilosa and Kilolo Districts, Tanzania. Int. J. Basic Appl. Res. Tanzania J. Agric. Sci., 13(2), 18-26. 
Ocholi, A., Nguwasen, A. V., Udeh, M. (2021). Effect of marketing intermediaries on pricing of onions in Benue State, Nigeria. J. Agribus. Rural Dev., 2(60), 133-141. http://dx.doi.org/10.17306/J.JARD.2021.01379

Nemeth, K., Piskula, M.K. (2007). Food content, processing, absorption and metabolism of onion flavonoid. Crit. Rev. Food Sci. Nutr. 47(4), 297-409.

Nigatu, G., Badau, F., Seeley, R., Hansen, J. (2020). Factors Contributing to Changes in Agricultural Commodity Prices and Trade for the United States and the World. Economic Research Report No. 272. Retrieved from: https://www. ers.usda.gov/publications/pub-details/?pubid $=95696$

Obasi, I.O., Emenam, O. (2014). Marketing Performance of Onions in Ikwuano and Umuahia Local Government Area, Abia State, Nigeria. Eur. J. Bus. Manag., 6(7), 136-140.

Obasi, I.O., Kalu, O.N. (2019). Structure and Efficiency of Onion Market in Umuahia Area of Abia State, Nigeria. Int. J. Econ. Bus. Manag., 5(1), 40-47.

Olukosi, J.O., Isitor, S.U. (1990). Introduction to Agricultural Marketing and Prices. Principle and application. Kaduna, Nigeria: Agitab Publishers.
Onu, J.I., Iliyasu, H.A. (2008). An Economic Analysis of the Food Grain Market in Adamawa State, Nigeria. World J. Agric. Sci., 4(5), 617-622.

Pelter, G.O., Sorensen, E.J., Thomton, R.E., Stevens, R. (2000). Dry bulb Onion production in the Columbia basin. Bull. EB1693. Pullman: Western Washington State University Cooperative Extension.

Sanusi, M.M., Dada, O.D. (2016). Profitability Analysis of marketing Tomato in Odeda Local Government Area of Ogun State, Nigeria. Ife J. Agric., 28(2).

Sulumbe, I.M. Shettima, B.G., John, T.B. (2015). An Analysis of the marketing of Onion in Monguno Local Government Area of Borno State, Nigeria. J. Market. Cons. Res., 13.

Tung, G.S., Lin, C.Y., Wang, C.Y. (2010). The Market Structure, Conduct and Performance Paradigm Re-applied to the International Tourist Hotel Industry. Afr. J. Bus. Manag., 4(6), 116-125. 